\title{
Wojna w Iraku oczami polskich i czeskich reporterów (na przykładzie tekstów Pawła Smoleńskiego, Mariusza Zawadzkiego, Michala Kubala, Františka Šulca i Barbory Šámalovej)
}

Tematem niniejszego tekstu są trzy reportaże książkowe tematycznie związane z konfliktem zbrojnym rozpoczętym atakiem koalicji sił międzynarodowych na Irak 20 marca 2003 roku (tak zwana druga wojna w Zatoce Perskiej) i/lub z sytuacją państwa irackiego w kolejnych latach. Dwie z analizowanych książek reporterskich napisane zostały po polsku (Paweł Smoleński, Irak. Piekło w raju, 2004; Mariusz Zawadzki, Nowy wspaniały Irak, 2012), autorami trzeciej książki jest troje czeskich dziennikarzy (Michal Kubal, František Šulc, Barbora Šámalová, Válka o Irák očima tři českých reportérů, 2004). Krótka analiza wymienionych tekstów oraz ich porównanie ukażą między innymi odrębne podejście polskich i czeskich reporterów do wspomnianego gatunku.

Obaj polscy reportażyści po raz pierwszy odwiedzili Irak jesienią 2003 roku. Ich podejście do tematu i - co za tym idzie - ich perspektywa reporterska okazują się jednak diametralnie odmienne. Choć Paweł Smoleński odwiedził Irak w momencie, kiedy polskie jednostki brały udział w operacjach militarnych koordynowanych przez Stany Zjednoczone, postanowił nie uprawiać tak zwanego embedded journalism. Dużo bardziej interesowała go iracka kultura, tradycja i mentalność, ale także 
sposób, w jaki Irakijczycy radzą sobie (albo nie radzą) z upadkiem reżimu Saddama Husajna, koalicyjną interwencją czy traumą przeszłości.

Mariusz Zawadzki przebywał w Iraku mniej więcej w tym samym czasie, co jego kolega z redakcji „Gazety Wyborczej”, ale w odróżnieniu od Smoleńskiego powracał do Bagdadu i okolic regularnie aż do 2009 roku. Ich teksty w pewnych kwestiach i tematach zbiegają się (obaj na przykład korzystali przez pewien czas z usług tego samego irackiego tłumacza), reportaże Mariusza Zawadzkiego mają jednak inny charakter - między innymi za sprawą szerszej perspektywy czasowej i strategii embedded journalism.

W wypadku czeskich reportaży o wojnie w Iraku sytuacja jest jeszcze bardziej skomplikowana. Wspomniana książka ukazała się w 2004 roku. Teksty autorstwa trojga dziennikarzy zredagowane zostały przez Zdeňka Šámala, w tym czasie dyrektora do spraw programów informacyjnych Czeskiej Telewizji. Każdy z czeskich reporterów pełnił inną rolę: Michal Kubal był — o ile mi wiadomo - jedynym czeskim dziennikarzem pracującym dla czeskich mediów, obserwującym amerykańską inwazję na Irak i późniejszy upadek reżimu Saddama Husajna bezpośrednio na miejscu, w Bagdadzie"; František Šulc, w tym czasie pracujący dla gazety „Lidové noviny”, w północnym Kuwejcie z bliska obserwował pracę tak zwanych Morskich Pszczół (Seabees), elitarnych oddziałów marynarki wojennej Stanów Zjednoczonych zajmujących się budową i utrzymaniem baz wojskowych, dróg, lotnisk itp.; Barbora Šámalová w różnych miejscach przyglądała się sytuacji po opanowaniu Iraku, dokumentując przykładowo działalność czesko-słowackiej jednostki antychemicznej stacjonującej w Kuwejcie, w obozie Mishrif.

\section{Irak. Piekło w raju}

Paweł Smoleński, reporter „Gazety Wyborczej”, odwiedził Irak kilka miesięcy po ataku koalicji sił międzynarodowych. Następnych kilkanaście tygodni spędził w Bagdadzie i innych irackich miastach w towarzystwie fotografa Krzysztofa Millera oraz irackiego tłumacza Dżamala Salmana. Zbiór reportaży Irak. Piekło w raju ukazał się w $2004 \mathrm{roku}^{2}$.

Spojrzenie Pawła Smoleńskiego na Irak jest spojrzeniem Środkowoeuropejczyka próbującego przynajmniej w pewnym stopniu zrozumieć skomplikowaną kulturę i historię tego kawałka świata oraz specyficzną mentalność Irakijczyków w obliczu zbrojnej interwencji obcych wojsk, koszmarnego (choć nie dla wszystkich, jak się okazuje) dziedzictwa reżimu Saddama Husajna czy prób zaszczepienia w ich państwie

\footnotetext{
1 Wojnę w Iraku relacjonował także Tomáš Etzler, pracujący jednak dla CNN.

2 W 2015 roku ukazał się czeski przekład książki (P. Smoleński, Irák. Peklo v ráji, przeł. M. Benešová, L. Zakopalová, Praha 2015).
} 
demokratycznego sposobu sprawowania władzy. W przeciwieństwie do Mariusza Zawadzkiego Smoleński nie jest zainteresowany operacjami militarnymi, nie współpracuje ani z amerykańską, ani z polską armią, aczkolwiek również jego (zwłaszcza w drugiej połowie książki) interesuje ówczesna iracka polityka oraz różne irackie „projekty na przyszłość". Z pomocą swojego tłumacza, który jest jednocześnie znakomitym przewodnikiem po obcym kraju, odwiedza bardzo różne środowiska, rozmawiając z bardzo różnymi bohaterami, co jest bez wątpienia jednym z największych atutów książki.

Zbiór reportaży Irak. Piekło $w$ raju odznacza się przemyślaną kompozycją. Nie jest tylko i wyłącznie zlepkiem oddzielnych tekstów - autor stosuje swoisty klucz tematyczny, na podstawie którego książka została podzielona na siedem części (aczkolwiek nienazwanych, a tylko numerowanych). Teksty składające się na poszczególne części zbiegają się tematycznie w bardziej uniwersalnych punktach, wskazując jednocześnie na podstawowe dylematy państwa borykającego się z okupacją, ciężarem przeszłości, terroryzmem i rodzącą się wojną domową. W części drugiej autor przedstawia ukryte pod postacią powszechnego strachu, kłamstwa oraz braku szacunku dla drugiego człowieka makabryczne dziedzict wo reżimu Saddama Husajna, w części trzeciej przybliża różne oblicza ówczesnego irackiego fundamentalizmu, w kolejnych (piątej i szóstej) opisuje sytuację polityczną w kraju po upadku Husajna i (w siódmej) odwiedza bagdadzkie slumsy - miejsca, które w oficjalnych przakazach medialnych są raczej pomijane.

Reportaże z tomu Irak. Piekło $w$ raju są dobrym przykładem reportażu literackiego. Biorąc pod uwagę klasyczne już dziś rozróżnienie Kazimierza Wolnego-Zmorzyńskiego kierujące się kryterium sposobu ukazania faktów, bliżej mają do tak zwanych reportaży fabularnych, których akcja - w odróżnieniu od reportaży problemowych - „koncentruje się wokół wydarzeń i bohaterów oraz obrazów i opisów z punktu widzenia reportera"3. Takiego typu reportaże swoją formą zbliżają się do gatunku opowiadania. Reportaże Pawła Smoleńskiego zwykle odznaczają się wyrazistą fabułą oraz zamkniętą kompozycją, przedstawiają rzeczywistość środkami charakterystycznymi dla literatury pięknej. Na pierwszy plan w jego tekstach wysuwają się obrazowość oraz fabularność jako podstawowe składniki reporterskiego spojrzenia na świat ${ }^{4}$. Spróbujmy przytoczyć parę przykładów.

W ramach korzystania ze środków pierwotnie literackich autor chętnie sięga zwłaszcza do języka metafory lub symbolu. Symboliczną wymowę ma już wstępny obraz bagdadzkiej mgły, w której nie można dostrzec nawet placu Al-Firdaus ${ }^{5}$. Nie

3 K. Wolny-Zmorzyński, Reportaż - jak go napisać?, Rzeszów 1996, s. 39.

4 Zob. J. Maziarski, Anatomia reportażu, Kraków 1964, s. 43-59. U Smoleńskiego kolejne dwa składniki, dokumentarność oraz nasycenie publicystyczne, schodzą poniekąd na drugi plan. Por. także: W. Furman, A. Kaliszewski, K. Wolny-Zmorzyński, Gatunki dziennikarskie. Specyfika ich tworzenia i redagowania, Rzeszów 2000, s. 63; K. Wolny-Zmorzyński, op. cit., s. 32-33.

5 P. Smoleński, Irak. Piekło w raju, Wołowiec 2012, s. 7. 
bez powodu autor wybiera właśnie plac Al-Firdaus, którego nazwa oznacza w tłumaczeniu na polski „raj”. To miejsce, gdzie pierwotnie stał pomnik Saddama Husajna, którego obalenie stało się w pewnym momencie symbolem nowej ery Iraku (zdjęcia z obalenia posągu swego czasu obiegły świat), a gdzie jesienią 2003 roku nieznani sprawcy pod osłoną nocy wymalowali napisy wyrażające wrogość wobec Amerykanów. Symbol wyzwolenia Iraku zamienia się w miejsce okryte złowrogą mgłą deformującą rzeczywistość, amerykańska utopia nowego Iraku zamienia się w koszmar codziennego chaosu oraz przemocy. Zaznaczmy już teraz, iż podobne postrzeganie wydarzeń w Iraku jako swoistej antyutopii charakterystyczne jest również dla Mariusza Zawadzkiego. Opis bagdadzkiej mgły Smoleńskiego jest na dodatek wyraźnie literacki, na pierwszy plan wysuwa się jego plastyczność, umacniana przez subiektywną perspektywę reportera (jakie stany wewnętrzne wywołuje w nim obraz mgły), użycie wyrazów ekspresywnych (choć w stopniu umiarkowanym) oraz zestawienie przeciwieństw uwidaczniających cechy charakterystyczne dla opisywanego zjawiska:

Ta cholerna mgła powinna uspokojać, ale drażni. Powinna usypiać, ale budzi. Niby łagodzi kontury miasta i zmiękcza proste, toporne kształty bloków z wielkiej płyty, lecz przywołuje lęki, fobie, baśnie o upiorach. [...] Bagdad we mgle straszy. Bardziej niż w pełnym słońcu, gdy wyje silnikami tysięcy samochodów, dusi się w oparach benzyny, topi w kałużach ropy, pokazuje przechodniom wypalone domy, dziurawe chodniki, wyrwane okna i drzwi, zadeptane trawniki, wyschnięte skwery, cokoły obalonych pomników. Dziś Bagdad jest po prostu paskudny ${ }^{6}$.

Innym razem, pisząc o dojściu Saddama Husajna do władzy, autor sięga po symbol stukania:

Wydawało się to czymś zupełnie niewinnym, drobiazgiem, błahostką, którą trudno przywołać w pamięci. [...] Otóż pewnego dnia (którego roku? Irakijczycy nie pamiętają nawet, który to był rok!) [...] portrety ówczesnego wiceprezydenta Iraku Saddama Husajna zawisły na tej samej wysokości co portrety prezydenta Hasana al-Bakra. [...] W tamtych dniach w całym kraju słychać było wielkie stukanie. $[\ldots]$ prawie nikt nie zwrócił uwagi na tamto wszechirackie stukanie i pukanie ${ }^{7}$.

Husajn od połowy lat siedemdziesiątych zdominował iracką politykę, faktycznym władcą Iraku został jeszcze przed oficjalnym odejściem al-Bakra na emeryturę w 1979 roku. Obraz „wielkiego stukania” jest więc u Smoleńskiego jednocześnie obrazem pełzającego przejęcia władzy i początku budowania kultu jednostki. Dla polskiego reportera staje się również punktem wyjścia nie tylko do krótkiego przedstawienia losów Saddama, zanim doszedł do władzy, ale - w kolejnych reportażach — także do szerszego odtworzenia sposobu funkcjonowania jego dyktatury. Smoleński zwraca uwagę między innymi na ciekawy wątek irackiej propagandy oraz funkcjonowania mediów za czasów Husajna ${ }^{8}$. Obraz Iraku sprzed 2003 roku jest oprócz tego systematycznie pokazywany poprzez historie konkretnych, „zwyczajnych” ludzi dotknię-

\footnotetext{
6 Ibidem, s. 9.

7 Ibidem, s. 15-16.

8 Ibidem, s. 27-28, 57-62, 72-83.
} 
tych Saddamowską dyktaturą, choć postrzegają ją w różny sposób (między innymi nauczycielka Chalida lawirująca między lojalnością i własnym sumieniem; były nauczyciel Dżabbar bojący się uczyć, ale także bojący się nie wiedzieć i z tego powodu odkrywający przeszłość Saddama; piosenkarka Samira; budowniczy Abu Ahmad, kiedyś realizujący „Wielkie Zlecenie”, budowę słynnego meczetu nazywanego Matką Wszystkich Bitew, a dzisiaj przyjmujący zlecenia od Amerykanów itp.).

Nie tylko Paweł Smoleński w swoich reportażach poświęca uwagę sytuacji irackich dziennikarzy, w odróżnieniu od Mariusza Zawadzkiego oraz czeskich reporterów skupia się jednak bardziej na czasach przed inwazją na Irak w 2003 roku. Przytacza na przykład historię dziennikarza Ahmada al-M. opowiadającego o tak zwanej czerwonej linii, granicy, której żaden iracki dziennikarz nie mógł przekroczyć, i o własnym zmaganiu się z brakiem wolności słowa. Chaotyczna wolność wprowadzona przez Amerykanów przeraża jednak Ahmada:

Jak w powodzi wolnych słów [...] odróżnić, które jest wolne dla samej wolności, a więc wolne buntowniczo, anarchizująco, w sumie szkodliwie, a które jest kreatywne, konstruktywne, odpowiedzialne? Wolne media to - zdaniem Ahmada - hasło tak uwodzicielsko piękne, że aż zwodnicze i niebezpieczne?.

W innych miejscach jednak sam reporter na własnej skórze poznaje, jak skomplikowana jest sytuacja zachodnich dziennikarzy w Iraku — po krwawych zamachach podczas obchodów szyickiego święta Aszura zmuszony jest do ucieczki, sam staje się wrogiem ${ }^{10}$.

Wracając do literackich walorów książki Irak. Piekło w raju, należy zwrócić uwagę na jeszcze jeden sposób pracy reportera z symbolami. Paweł Smoleński często przedstawia pewne słynne, prawie kultowe obrazy, powszechnie kojarzone z kluczowymi wydarzeniami z irackich dziejów, nie robiąc z nich jednak głównych tematów poszczególnych reportaży i jednocześnie nie wyjaśniając w prosty sposób (a więc ściśle informacyjny) ich znaczenia. Zamiast informacji otrzymujemy obraz.

Oprócz wspomnianego już placu Al-Firdaus funkcję takiego symbolicznego obrazu powiązanego z kluczowymi historycznymi lub aktualnymi wydarzeniami oraz odsyłającego do bardziej złożonej rzeczywistości pełnią również na przykład telewizyjne nagrania rozstrzelanego generała Kasima po przejęciu władzy przez partię Baas w 1963 roku, śmierć czterech pracowników ochroniarskiej firmy Blackwater pod koniec marca 2004 roku oraz publiczne zbeszczeszczenie ich zwłok czy budowa meczetu Matka Wszystkich Bitew na cześć irackiego heroizmu podczas pierwszej wojny w Zatoce Perskiej, inicjująca budowanie coraz większych meczetów, już wyłącznie na cześć samego dyktatora. Co ciekawe, takie obrazy nie mają w ujęciu Smoleńskiego charakteru statycznego - na ich przykładzie reporter pokazuje sytuacje zmieniające się w czasie lub zmieniające się znaczenia takich obrazów.

${ }^{9}$ Ibidem, s. 63.

10 Zob. ibidem, s. 118, 143-144. 
Nie zamierzam w tym miejscu w bardziej szczegółowy sposób przypominać podstawowych ról, jakie reporter może przyjmować w swoim tekście ${ }^{11}$. W reportażach Pawła Smoleńskiego najczęściej mamy do czynienia z rolami słuchacza, obserwatora (świadka) i/lub uczestnika wydarzeń. Z punktu widzenia narracji reportaże z książki Irak. Piekło $w$ raju dowodzą tezy Zygmunta Ziątka, iż polski reportaż powojenny w dużej mierze (wyraźniej niż do tej pory) oparty jest na rozmowie ${ }^{12}$. Takie podejście jednocześnie akcentuje rolę świadków, a więc rozmówców reportera. Reporter staje się w takiej sytuacji przede wszystkim słuchaczem. Z tego powodu Paweł Smoleński chętnie przytacza (albo wprost cytuje) wypowiedzi swoich bohaterów, spora część jego tekstów strukturalnie oparta jest właśnie na dialogach — wypowiedziach subnarratorów. Aby osiągnąć narrację wielopłaszczyznową, stosuje na przemian perspektywę narratora (narrator tożsamy jest w tym wypadku z podmiotem autorskim) oraz perspektywę poszczególnych rozmówców, zazwyczaj jednak bez komentarza. Na przykład całe części druga albo szósta książki bazują na wypowiedziach Irakijczyków, z którymi reporter nawiązał kontakt; zdominowane są one przez sytuację rozmowy. W takich fragmentach sam reporter (narrator) często schodzi na drugi plan.

Ciekawym przykładem jest tekst (reportaż drugi z części czwartej) opisujący spotkanie reportera z Mustafą, mudżahedinem, który wprowadza Smoleńskiego w świat tych, którzy jako członkowie „armii Boga” walczą przeciwko okupantom. Razem odwiedzają Al-Falludżę, miasto, które stało się symbolem zaciętych walk pomiędzy sunnickimi rebeliantami i amerykańskimi oraz irackimi żołnierzami. Paweł Smoleński dociera do Mustafy oraz jego kolegów „w sposób niebudzący podejrzeń” ${ }^{13}$ — w jaki konkretnie, tego jednak reporter, prawdopodobnie chroniąc swoje źródła, nie zdradza. Wiemy tylko, że spotkali się przez pośredników ${ }^{14}$. Mustafa przedstawi polskiego reportera swoim kolegom, którzy dyskretnie, prawie konspiracyjnie wożą go w terenówce ulicami Al-Falludży, opowiadając o tym, co robią, i tłumacząc, jakie są ich zamiary. Reporter w żaden sposób nie ujawnia otwarcie własnego zdania (nie tylko w czasie rzeczywistym, wysłuchując opowieści mudżahedinów, ale także pisząc swój reportaż), swoją rolę ogranicza do roli słuchacza:

Będą mówić obaj: Mustafa i Amir, ten nowy pasażer, ubrany w lichy, powyciągany dres. Nie sprzeczają się, nie wpadają sobie w słowo. Pierwszy czytał myśli drugiego, drugi podejmował wątek, który rozpoczął pierwszy. Byli jak jedne usta i jedna dusza, zgodni w myśli i w każdym słowie. Nie spierałem się z nimi, nie komentowałem. Chciałem po prostu ich wysłuchać ${ }^{15}$.

11 Zob. na przykład K. Wolny-Zmorzyński, op. cit., s. 96-98.

12 Z.Ziątek, Problem intermedialności reportażu międzywojennego, [w:] Reportaż w dwudziestoleciu międzywojennym, red. M. Piechota, K. Stępnik, Lublin 2004, s. 16.

13 P. Smoleński, Irak..., s. 94.

14 „Spotkaliśmy się przez pośredników. Na początku nie ufałem mu i on mi nie ufał, ale to ja koniec końców byłem na niego skazany. Nigdy mnie nie zawiódł" — ibidem, s. 99.

15 Ibidem, s. 93. 
Głos sunnickich rebeliantów z Al-Falludży wyważa Smoleński opowieściami innych rozmówców w kolejnych tekstach lub prostym przytaczaniem faktów, których wymowa jasna jest nawet bez odautorskiego komentarza ${ }^{16}$. Książkę jako całość charakteryzuje dzięki temu wielowątkowość - reporter oddaje głos bardzo różnym środowiskom.

Czasami role obserwatora i uczestnika wydarzeń zlewają się. Taką postawę określić można jako postawę obserwatora zaangażowanego. W książce Smoleńskiego najlepszym tego przykładem jest szósty reportaż z części czwartej opowiadający o doświadczeniach reportera, który stał się świadkiem rytuału członków mistycznej sekty sufi. Razem z fotografem Krzysztofem Millerem i tłumaczem Dżamalem Salmanem mają okazję obserwować obrzęd dostępny zazwyczaj tylko wtajemniczonym, podczas którego sufici w religijnym transie przebijają sobie ciała szpikulcami, tańczą i śpiewają. Reporter staje się tutaj nie tylko obserwatorem, ale w pewnym stopniu na własnej skórze przeżywa efekty mistycznego uniesienia, chociaż w żaden sposób nie ingeruje w obserwowaną rzeczywistość, a "tylko” emocjonalnie przeżywa sceny rozgrywające się na jego oczach. Okazuje się bowiem, że w takiej sytuacji nie można pozostać tylko obserwatorem. Słychać rytm bębnów, zbiorowy śpiew mężczyzn, coraz bardziej głośny i dynamiczny, niektórzy z nich zaczynają wbijać sobie w ciała długie szpikulce...

Nikt nie usiedzi na miejscu, nawet dostojny szajch Ahmad [...]. Tłum krzyczy, bije się w piersi, skacze. To już nie trans, nie hipnotyzująca ceremonia. Ale co? — nie mam pojęcia. Gdzie jestem? Co tu robię? Jak mogę zachować przytomność umysłu? Nawet bębny, kpiąc z prawa ciążenia, fruwają w powietrzu, podbijane rytmicznymi uderzeniami. Nie mogę wysiedzieć, bezwiednie klaszczę w rytm bębnów, kołyszę się, skanduję. [...] Gdzie jest Krzysiek?17

Opisywane wydarzenia pokazane są przez pryzmat podmiotu przeżywającego (nie tylko obserwującego). Słowa reportera oddają atmosferę sytuacji. Jak wytłumaczyć sobie w sposób racjonalny, co dzieje się na dziedzińcu medresy? Autor sięga po nacechowane emocjonalnie słownictwo, stosuje krótkie, urwane zdania, sam sobie zadaje pytania, przyznaje się do tego, że choć nie włącza się aktywnie w wydarzenia, czuje się

16 Przykładem może być właśnie reportaż o mudżahedinach, w którym reporter tak uzupełnia charakterystykę swojego rozmówcy: „Wydaje mi się, że widziałem Mustafę na przerażających zdjęciach, portretujących oszalały tłum masakrujący martwe ciała czterech amerykańskich ochroniarzy zabitych na autostradzie blisko Al-Falludży. Te fotografie profanowanych zwłok stały się dla cywilizowanego świata przykładem zezwierzęcenia i bestialstwa" - ibidem, s. 99. Jedynym elementem własnej opinii autora jest tutaj słowo „przerażający”, aczkolwiek nawet z nim (lub jego subiektywnością) trudno polemizować. Jeśli już pojawia się komentarz reportera, zazwyczaj jest ostrożny i dotyczy sytuacji, które autor uważa za nader absurdalne. Kiedy na przykład pyta o odpowiedzialność za zamachy w czasie obchodów święta Aszura, wypowiedź fundamentalistycznego wahhabity Madżida („Pytam Madżida, kto - wedle jego zdania - jest odpowiedzialny za straszliwe zamachy w ostatni dzień szyickiego święta Aszura? Odpowiada bez namysłu: masoni” — ibidem, s. 125) prowokuje go do nieco ironicznej riposty: „Skąd w Iraku masoni? [...] Szajchu - mówię - coś nie chce mi się wierzyć w tych masonów" - ibidem, s. 126.

17 Ibidem, s. 129, 131.

Dziennikarstwo i Media 9, 2018

(C) for this edition by CNS 
emocjonalnie zaangażowany. Jego pierwotna rola obserwatora zamienia się w postawę kogoś, kto nie tylko opisuje, ale także przeżywa. Na dodatek nie do końca rozumie, czego był świadkiem: „Jak długo to trwało? Kwadrans? Dziesięć minut? Minutę? Co tu się działo jeszcze przed chwilą? Obłęd? Zbiorowa histeria? Natchniona, religijna ekstaza? Nie rozumiem i nie wiem, choć wszystko widziałem i wszystko czułem"18.

Omawiany reportaż nie wiąże się bezpośrednio z tematyką wojny w Iraku. Wracając do wstępnych uwag, również w tym tekście autora interesuje raczej szerszy kontekst irackiej kultury i mentalności, który zostaje jednak nieodzownym tłem wydarzeń z 2003 roku.

Jacek Maziarski twierdzi, iż fabularność reportażu literackiego przejawia się w tekście w przewadze tak zwanych ujęć przedstawiających akcyjnych, to znaczy takich, które komunikują fakty w sposób obrazowy ${ }^{19}$. Omawiany tekst odznacza się dużą dozą literackości, obrazowe przedstawienie rzeczywistości staje się jego podstawą. Ważne jest oddanie atmosfery opisywanego wydarzenia — właśnie obrazowość uwydatnia specyficzny nastrój chwili, ale także emocjonalne zaangażowanie reportera, które trudno oddać w prosty opisowy albo informujący sposób. Czasami, by wzmocnić wypowiedź i podkreślić jej subiektywność, autor sięga po ekspresywne środki językowe (wykrzyknienia, pytania retoryczne, powtórzenia niektórych wyrazów itp.), na przykład: „To, co dzieje się na dziedzińcu, to cały czas mało, mało, mało"20. Wyraźnie akcentowane jest tempo narracji (coraz szybsze; autor stopniuje napięcie, co cały czas koresponduje z jego własnym przeżywaniem sytuacji) oraz dynamizm wypowiedzi (co podkreślają krótkie zdania, często proste). Z takim samym obrazowym odtworzeniem rzeczywistości mamy do czynienia również w innych tekstach Smoleńskiego, na przykład w reportażu o szyickim święcie Aszura ${ }^{21}$.

W ostatniej części książki Paweł Smoleński zbliża się poniekąd do reportaży Mariusza Zawadzkiego, pokazuje bowiem przede wszystkim dylematy Iraku po upadku reżimu Saddama Husajna, łącznie z tymi politycznymi. W odróżnieniu od Zawadzkiego (jak zobaczymy w następnej części tekstu) nie jest zainteresowany operacjami wojskowymi oraz polityką Stanów Zjednoczonych. Bardziej skupia się na postawach swoich rozmówców reprezentujących wszystkie ważne środowiska spierające się w pierwszych miesiącach 2004 roku o przyszłość Iraku (mocni szajchowie; ajatollah As-Sistani, choć akurat z nim - z wiadomych powodów - autor nie spotkał się, przytacza „tylko” różne opowieści o nim; liberałowie i demokraci; działacze Irackiej Partii Komunistycznej; szef miejscowej rady podporządkowanej amerykańskiej administracji; iracki doradca tejże administracji; działaczka Ligi Kobiet Irackich itp.). Swoistym prologiem do tych rozdziałów staje się rozmowa reportera z szajchem Ha-

\footnotetext{
18 Ibidem, s. 132.

19 J. Maziarski, op. cit.

20 P. Smoleński, Irak..., s. 130.

21 Zob. ibidem, s. 135-147.
} 
midem, głową plemienia Obejdi, który dzięki sieci informatorów prowadzi swoją własną politykę i - jak się później okazuje - przepowiada przyszłe losy państwa irackiego oraz problemy, z którymi Irak będzie się borykał (bezradność irackiej Rady Zarządzającej, kwestia autonomii kurdyjskiej, brak tradycji demokratycznej w Iraku, wybuch szyickiej rebelii reprezentowanej przez tak zwaną Armię Mahdiego itp.), choć jego interpretacja faktów bywa stronnicza (zob. „dowody” szajcha dotyczące znalezienia resztek Saddamowskiej broni masowego rażenia przez jego ludzi) ${ }^{22}$.

To wszystko raz jeszcze świadczy o starannie przemyślanej kompozycji książki Irak. Piekło w raju. Amerykanie pojawiają się w reportażach Pawła Smoleńskiego tylko pośrednio ${ }^{23}$. Przyjęta perspektywa różni się więc zasadniczo od perspektywy drugiego polskiego reportera piszącego o wojnie w Iraku i jej konsekwencjach Mariusza Zawadzkiego.

\section{Nowy wspaniały Irak}

Książka Mariusza Zawadzkiego Nowy wspaniały Irak przedstawia irackie wydarzenia w zasadzie chronologicznie - poszczególne rozdziały opowiadają o latach 20032009. Relacje $z$ aktualnych wydarzeń uzupełniane są historycznymi dygresjami lub krótkimi reminiscencjami lat minionych (wyjątkiem jest rozdział zatytułowany Sir Winston Churchill i jego czterdziestu rozbójników w całości traktujący o powstaniu państwa Irak).

Już sam tytuł, będący aluzją do słynnej powieści Aldousa Huxleya Nowy wspaniały świat, nasuwa na myśl ogólną perspektywę przyjętą przez polskiego reportera - tak angielski powieściopisarz, jak Mariusz Zawadzki stwarzają pewną antyutopię. Nowy Irak po upadku reżimu Saddama Husajna szybko pogrąża się w chaosie oraz swoistej wojnie domowej, marzenia amerykańskich wyzwolicieli o nowym porządku opartym na demokratycznych zasadach zamieniają się w koszmar. W centrum zainteresowania Zawadzkiego znajduje się nieudana próba zaszczepienia w Iraku demokracji

22 Ibidem, s. 165-173.

23 Wyjątkiem jest czwarty reportaż z części trzeciej traktujący o zamachach w Samarze, gdzie Smoleński - wyjaśniając narastające zdenerwowanie amerykańskich żołnierzy — przytacza na przykład osobiste wspomnienia momentu, kiedy razem z nimi utknął w windzie: „Było pod wieczór, w holu, na skórzanych fotelach, siedziało kilkunastu żołnierzy. Żartowali z nas, stroili głupie miny, krzyczeli w radiotelefon: "Zawołać wam CNN? A może wolicie być w NBC? «. Na początku wszystkim było wesoło. Później nastroje nieco się popsuły. [...] I wówczas w blondasa wstąpił diabeł. Zacisnął szczęki, warknął w radiotelefon: "Jeśli za pięć amerykańskich minut będę tu jeszcze siedział, rozpieprzę wszystko «. Włożył hełm, zapiął kamizelkę, przeładował karabin. Jego podwładni zrobili to samo. Widziałem, jak z wściekłości trzęsą się im ręce. [...] Blondas uważnie wpatrywał się w tarczę zegarka. Nic go nie obchodziło, że w windzie są ludzie, którzy nie nałożą hełmów i kamizelek kuloodpornych, bo ich po prostu nie mają. [...] Wcześniej nie umiałem sobie wyobrazić, jak bardzo muszą być zdenerwowani, gdy jeżdżą ulicami Bagdadu" - ibidem, s. 112-113. 
i stworzenia demokratycznego państwa, a więc zderzenie dwóch światów - świata irackiego, islamskiego i postsaddamowskiego ze światem Zachodu. Znaczącą rolę odgrywa więc w jego reportażach polityka, strategia wojskowa Amerykanów, ale także osobiste, czasami wprost przygodowe przeżycia reportera.

Swoją książkę Zawadzki otwiera historyczną paralelą - najazd Mongołów na Bagdad w 1253 roku zestawiony zostaje z amerykańską interwencją w Iraku, podobieństwa reporter znajduje zwłaszcza w zlekceważeniu nieprzyjaciół przez ówczesnych władców Iraku. Strategię tę stosuje Zawadzki stosunkowo często - część jego reportaży zbudowana jest na zasadzie kontrastu (współczesność versus przeszłość). (W innym miejscu Pax Americana, czyli próba narzucenia światu przez dowództwo amerykańskich sił zbrojnych własnej wizji porządku, zestawiony został z Pax Mongolica, dążeniem do zorganizowania jak największych obszarów świata na wzór imperium mongolskiego ${ }^{24}$.) Taka paralela implikuje jeszcze jedno ważne pytanie: co odróżnia Irak od świata zachodniego, a co jest więc podstawą nieporozumienia, z którym Amerykanie (w pewnym sensie główni bohaterowie reportaży z tomu Nowy wspaniały Irak) bedą się borykać przez cały czas trwania wojny? ${ }^{25}$

Taki chwyt - wskazywanie na pewne stałe cechy świata irackiego poprzez paralelizmy - Mariusz Zawadzki stosuje relatywnie często. W różnych czasach powraca do tych samych miejsc, pokazując w ten sposób zmieniające się nastroje lub sytuację polityczną. Pierwszą podróż do Bagdadu odbywa jesienią 2003 roku, do stolicy dociera samochodem w towarzystwie dwóch palestyńskich kierowców oraz jednego kałasznikowa („Ale wtedy nie czuło się żadnego zagrożenia”26). Po raz drugi, w kwietniu 2004 roku, akurat w czasie szturmu na Al-Falludżę, miejscowych kierowców jest więcej, tak samo jak broni palnej: „Już od samej granicy było inaczej”. „Nie domyślałem się, że przekraczam bramę piekieł"27. Piekło irackiej wojny otwierają czytelnikowi kolejne reportaże $\mathrm{z}$ omawianego tomu.

W reportażach Mariusza Zawadzkiego często stosowana jest bezpośrednia charakterystyka bohaterów (albo rozmówców). To przykład obiektywizacyjnej strategii polskiego reportera, podobnie jak przytaczanie innych materiałów, na przykład dokumentów amerykańskiej armii lub wybranych prac historycznych (należy jednak zwrócić uwagę, że chodzi o zabieg dosyć „konserwatywny” oraz tradycyjny, prawdziwy intertekstualny dialog w reportażu można prowadzić w dużo bardziej wyrafinowany sposób, przykładem czego niech będą klasyczne już dzisiaj Podróże z Herodotem Ryszarda Kapuścińskiego). Taka strategia zazwyczaj ma na celu nie tylko dodanie wiarygodności (wzmacnia faktograficzny wymiar tekstu), ale także merytoryczne

24 M. Zawadzki, Nowy wspaniały Irak, Warszawa 2012, s. 24.

25 „Bagdadczycy są przekonani, że gdyby nie najazd Mongołów, to właśnie ich miasto, a nie Nowy Jork, Paryż czy Londyn, byłoby dzisiaj stolicą świata” — ibidem, s. 9.

26 Ibidem, s. 16.

27 Ibidem, s. 42. 
uzupełnienie - nie zaś zasadniczą semantyczną innowację tekstu lub jego problematyzację, jak miało to miejsce w wypadku Kapuścińskiego.

Nie przypadkowo typowymi bohaterami reportaży Zawadzkiego są amerykańscy żołnierze, dyplomaci (na przykład polski ambasador w Bagdadzie, zob. reportaż Lękliwy stokroć umiera przed śmiercią) czy miejscowi iraccy przedstawiciele (z różnych stron politycznego spektrum, zob. na przykład rozmowę z szejkiem Abdulem Sattarem al-Bahadlim, jednym z dowódców Armii Mahdiego w Basrze oraz, jak pisze autor, „archetypem arabskiego gangstera” ${ }^{28}$.

W tekstach z tomu Nowy wspaniały Irak cały czas przeplatają się opisy sytuacji oraz wydarzeń, których reporter sam był świadkiem, historyczne dygresje mające na celu wprowadzenie czytelnika w szerszy kontekst wojny irackiej oraz sytuacji politycznej Iraku na początku XXI wieku, obserwacje szczegółów życia codziennego Irakijczyków (chociaż akurat takich fragmentów jest w książce znacznie mniej niż w reportażach Pawła Smoleńskiego) i własne przeżycia reportażysty (nieraz przypominające opowieść przygodową, czasami będące ilustracją ogólnych obserwacji). Spore fragmenty tekstu pełnią raczej funkcje informacyjne, wprowadzają czytelnika w tematykę, pokazują szerszy kontekst historyczny, polityczny lub kulturowy, przytaczając podstawowe fakty. W takich miejscach Zawadzki wykorzystuje sposób komunikowania faktów, który można za Jackiem Maziarskim nazwać ujęciami informacyjnymi, gdzie najważniejsze są właśnie same fakty, logicznie powiązane oraz pełniące przede wszystkim funkcję informacyjną ${ }^{29}$.

Nie zawsze da się jednak jednoznacznie skonstatować, czy dany fragment tekstu stanowi przykład tak zwanego ujęcia informacyjnego statycznego czy zbliża się raczej do ujęcia przedstawiającego, charakteryzowanego przez Maziarskiego jako ujęcie zdolne wywoływać po stronie czytelnika przedstawienia wyobrażeniowe ${ }^{30}$. Przykładem może być rozdział zatytułowany Jaka piękna katastrofa, w którym polski reportażysta odwiedza Irak w czasie pierwszego szturmu na Al-Falludżę i w skrócie stara się czytelnikom przybliżyć, skąd bierze się ówczesny konflikt między szyitami i sunnitami. Do tego służy kolejna dygresja historyczna, tym razem zestawiająca dwie skrajnie różne interpretacje bitwy pod Karbalą w 680 roku - sunnicką oraz szyicką. Autor przytacza znane fakty, ale nie tylko. Fakt (w tym wypadku wydarzenie historyczne) jest dla niego czymś wielowymiarowym, czymś, co - tylko na pierwszy rzut oka paradoksalnie - zawiera w sobie różne wersje (a więc interpretacje) tegoż wydarzenia, które są wśród danego społeczeństwa powszechnie przyjmowane. $\mathrm{Na}$ podanym przykładzie dobrze widać, jak odrębne wersje tej samej historii stwarzają bardzo odmienne wizje świata, niedające się później w prosty sposób pogodzić.

\footnotetext{
28 Ibidem, s. 127.

29 J. Maziarski, op. cit.

30 Ibidem, s. 128.
} 
Zawadzki przygląda się historii również w jej wymiarze alegorycznym, traktując los zamordowanego imama Husajna jako alegorię późniejszego losu szyitów w ogóle. W ten sposób problematyzuje jednoznaczność faktów historycznych, skupiając się raczej na ich różnorodnych interpretacjach. Wracając do rozróżnienia Jacka Maziarskiego, Mariusz Zawadzki często waha się pomiędzy dwoma podstawowymi rodzajami przekazu — informacją oraz obrazem. Powstanie szyitów (jako główny wątek wspomnianego rozdziału) pokazywane jest więc w szerszym kontekście historycznym, ale również religijnym i obyczajowym.

Znaczący jest także sposób wykorzystywania ironii przez Zawadzkiego. Już sam tytuł wyżej wspomnianego rozdziału, Jaka piękna katastrofa, zdaje się mieć ironiczny wydźwięk. Ironia występuje w tekstach polskiego reportażysty w różnym nasileniu i jako kategoria estetyczna służy między innymi do wyrażania negatywnego stosunku albo przynajmniej dystansu autora do opisywanej rzeczywistości. Jest więc jednym ze środków, z pomocą których autor wplata w swój tekst elementy subiektywne, konstytutywne dla gatunku reportażu literackiego. Postawa autora wobec działań Amerykanów w Iraku wyrażana jest więc - chociaż nie wprost i otwarcie - na przykład w słowach o „szlachetnych i pożytecznych” celach przyświecających Waszyngtonowi podczas podejmowania decyzji o zbrojnej interwencji: „Czyż mogło być coś piękniejszego dla Bliskiego Wschodu, dla Ameryki i dla całej ludzkości?"31

W innych miejscach owa ironia może być bardziej kontrowersyjna. Opowiadając o wyjeździe do Basry oraz zagrożeniach, z jakimi zachodni dziennikarze mogą się spotkać w tym mieście, autor w pewnym momencie „żałuje”, że dzięki sprytnej sztuczce udało mu się uniknąć porwania: „[... [ zacząłem nawet trochę żałować, że nie zostanę uprowadzony. Jak na irackie standardy porwanie zapowiadało się niewinnie, a przyniosłoby mi rozgłos. Wracałbym do Polski jako bohater, na Okęciu witałyby mnie wszystkie telewizje, a może nawet przyjąłby mnie premier"32. Tytuł omawianego rozdziału wybrzmiewa w końcu również ironicznie, w tym wypadku gorzko ironicznie - Wakacje w Basrze.

Czasami Zawadzki sięga nawet po komizm sytuacyjny (jeśli pozwolimy sobie na zastosowanie pojęć właściwych raczej literaturze), na przykład w momentach, kiedy sam jako autor/reporter eksponuje własną rolę w tekście, kiedy staje się jednym z bohaterów własnych reportaży. Przyjrzyjmy się więc bliżej jeszcze jednej zasadniczej charakterystyce irackich reportaży Mariusza Zawadzkiego dotyczącej sposobu jego pracy oraz roli samego reportera w tekstach. Zawadzki uprawia między innymi tak zwany embedded journalism - formę dziennikarstwa, która zaczęła być powszechnie wykorzystywana właśnie w czasie wojny w Iraku. Reporter w takiej sytuacji podróżuje z żołnierzami, mieszka w ich bazie, dołącza do ich patrolów i bezpośrednio obserwuje działania wojenne. Może też korzystać z dostępu do centrów informacyjnych armii.

31 M. Zawadzki, op. cit., s. 26.

32 Ibidem, s. 135. 
(Właśnie takiego dziennikarstwa nie chciał uprawiać Paweł Smoleński.) Mariusz Zawadzki z bliska obserwuje na przykład obławę na terrorystów związanych z Al-Kaidą w miejscowości Husajba przy granicy z Syrią albo bierze udział w amerykańskim patrolu w Bakubie. Embedded journalist zostaje przydzielony do jednego z oddziałów wojsk koalicyjnych ${ }^{33}$, co daje mu ochronę i dostęp do informacji, ale również w pewnym stopniu ogranicza jego wolność i - zdaniem niektórych - także jego obiektywizm (czasami embedded journalism uważany jest wprost za część propagandy wojennej) $)^{34}$.

Na dodatek reporter pojawia się wśród Irakijczyków w otoczeniu amerykańskich żołnierzy, w kamizelce kuloodpornej (chociaż Zawadzki często podkreśla niechęć do korzystania $z$ niej), na tle broni palnej trzymanej przez żołnierzy. W odczytaniu miejscowych staje się więc jednym z najeźdźców, jak później wspominał sam Zawadz$\mathrm{ki}^{35}$. To zresztą nie jedyny powód, dla którego dziennikarze zagraniczni stawali się w Iraku ofiarami porwań, napadów lub zabójstw ${ }^{36}$.

Jednocześnie obserwacje Zawadzkiego nie kończą się zawsze tylko na opisie operacji wojskowych. Przykładowo jego doświadczenia jako embedded reporter z Bakuby prowadzą w drugiej części reportażu do ciekawego, choć oszczędnego przedstawienia podstawowych nieporozumień pomiędzy przedstawicielami amerykańskich sił zbrojnych a miejscowymi szejkami.

Refleksja na temat pracy dziennikarzy w Iraku jest ciekawym wątkiem nie tylko reportaży Mariusza Zawadzkiego. Właśnie on poświęca jednak dużo uwagi zarówno sposobom pracy swoich kolegów po fachu, jak i własnej roli w opisywanej rzeczywistości. Zanim dołączy do grupy embedded reporters, opisuje „kamuflaże”, które miały jemu i jego tłumaczowi pomóc wtopić się w iracką ulicę. Nawet taki opis nie stroni jednak od (auto)ironii:

33 Magdalena Hodalska podaje, iż takich dziennikarzy było w tym czasie w Iraku 500 (M. Hodalska, Korespondent wojenny: ofiarnik i ofiara we współczesnym świecie, Kraków 2014, s. 55), Łukasz Szurmiński pisze o liczbie 600 (Ł. Szurmiński, Media na wojnie - modele relacji wojsko-dziennikarze na przykładzie konfliktów zbrojnych w XX i XXI wieku, 2011, https://depot.ceon.pl/bitstream/handle/123456789/1149/Media\%20na\%20wojnie\%20-\%20Manipulacja\%20w\%20mediach....pdf?sequence=1, s. 18 [dostęp: 14 grudnia 2018]). Szurmiński opisuje również zespół zasad przygotowany przez Departament Obrony USA, które dziennikarz przed wyjazdem na misję musiał zaakceptować.

34 Słowa Mariusza Zawadzkiego zdają się niekiedy taką opinię potwierdzać: „Amerykańscy żołnierze w Iraku nie mieli przed dziennikarzami niemal żadnych tajemnic. Chcieli, żeby świat dowiedział się o ich ofiarach, sukcesach i ciężkiej pracy. [...] Dziennikarze byli przez nich rozpieszczani. Czasami czułem się niemal, jakby mnie przekupywali” - M. Zawadzki, op. cit., s. 140.

35 M. Zawadzki, Dziennikarz, czyli wróg, "Gazeta Wyborcza” 2-3 maja 2005, s. 10. Zob. także M. Zawadzki, Nowy wspaniały Irak..., s. 76.

36 Więcej zob. M. Hodalska, op. cit., rozdział Irak - polowanie na dziennikarzy. 
My z Tahsinem próbowaliśmy kamuflażu prasowego. Kupowaliśmy arabską gazetę, którą na niby czytałem na tylnym siedzeniu jego peugeota, chowając twarz. Robiliśmy w gazecie małą dziurkę, jak na filmach szpiegowskich klasy B, żebym mógł zerkać, co dzieje się na ulicy ${ }^{37}$.

Zawadzki opisuje również pracę zachodnich dziennikarzy zabarykadowanych w hotelach odgrodzonych od rzeczywistego świata irackiej wojny wysokim betonowym murem (spostrzeżenia te odnoszą się do sytuacji z 2005 roku, a więc już po fali masowych porwań cudzoziemców, łącznie z dziennikarzami, z kwietnia i czerwca 2004 roku). Różnica w pracy reporterów poszczególnych mediów polegała z grubsza na tym, że ci z dużych agencji mogli sobie pozwolić na zatrudnienie informatorów przekazujących im informacje z Bagdadu ${ }^{38}$. W związku ze specyficzną pozycją polskich reporterów (oczywiście ze względu na udział Wojska Polskiego w interwencji zbrojnej w Iraku) Zawadzki opisuje również niektóre strategie stosowane przez niego w celu zdobycia informacji — razem ze swoim tłumaczem udawali na przykład dziennikarzy rosyjskich ${ }^{39}$.

Pojedyncze obserwacje przeradzają się czasami w ogólniejsze refleksje na temat pracy dziennikarzy w trudnych warunkach. Reporter „Gazety Wyborczej” pisze między innymi o pewnym poczuciu winy, kiedy jako obcokrajowiec wraca do Polski, a swoich rozmówców zostawia na miejscu.

Dla mnie właśnie kończyła się kolejna przygoda. [...] Zawsze wiedziałem, że za miesiąc mam wrócić do normalnego świata. Na miejscu zostawiałem ludzi, którzy [...] nie przyjechali tam na ochotnika; nie wsiądą w samolot, żeby polecieć do domu, a potem w wygodnym fotelu wspominać okrutną i absurdalną bajkę z Bagdadu ${ }^{40}$.

Przeżycia polskiego reportera mają czasami również wymiar osobisty. Tak jest w wypadku losu tłumacza Dżamala Salmana (pracującego także dla Pawła Smoleńskiego), zamordowanego w sierpniu 2004 roku przez grupę Ansar as-Sunna za to, że współpracował z polskimi dziennikarzami ${ }^{41}$.

Najbardziej ciekawym, ale także najbardziej kontrowersyjnym ze względów etycznych zabiegiem, jaki reporter stosuje w celu uatrakcyjnienia swojego tekstu, jest bezpośrednia ingerencja w opisywaną rzeczywistość. Przyjmuje on wtedy rolę bezpośredniego uczestnika wydarzeń, które na dodatek w dużej mierze sam stwarza. Należy

37 M. Zawadzki, Nowy wspaniały Irak..., s. 76.

38 Ibidem, s. 75-76.

39 Ibidem, s. 57.

40 Ibidem, s. 61. Zawadzki nie jest oczywiście jedynym dziennikarzem, który artykułuje podobne dylematy (nie tylko we własnych reportażach, ale także w komentarzach do nich, wywiadach czy innych publicznych wypowiedziach). Jego słowa stanowią raczej potwierdzenie głosu bardziej uniwersalnego, nie są zatem zaskakującym wyznaniem reportera pracującego w trudnych warunkach. Zob. na przykład wspomnienia fotografa Krzysztofa Millera (K. Miller, 13 wojen i jedna. Prawdziwa historia reportera wojennego, Kraków 2013), reportaże Artura Domosławskiego z tomu Wykluczeni (Warszawa 2016) czy książkę Wojciecha Tochmana Eli, Eli (Warszawa 2013).

41 M. Zawadzki, Nowy wspaniały Irak..., s. 61-62. 
oczywiście dodać, iż jednym z celów bywa w takich sytuacjach zdobycie informacji poprzez sprowokowanie wydarzeń, spojrzenie na wybrany temat $\mathrm{z}$ innego punktu widzenia (perspektywa z zewnątrz versus perspektywa wewnętrzna) lub zdemaskowanie jakiegoś zjawiska. Autor nie korzysta jednak z takich zabiegów w sposób, jaki zazwyczaj kieruje pracą tak zwanych dziennikarzy śledczych. Również on stosuje ukryte techniki zdobywania informacji, ale nie robi tego w pierszej kolejności po to, żeby zbadać pewne środowisko czy zdemaskować nielegalne postępowanie. Chcąc opisać tło irackiego handlu bronią, Zawadzki postanowił kupić rakietę ziemia-powietrze. W tym celu spotkał się z tajemniczym Pułkownikiem, dawnym oficerem Saddamowskiej armii, nie zdradzając mu jednak swojej prawdziwej tożsamości. Co prawda, udało mu się kupić rakietę, ale nie wiedział, co z nią zrobić i jak z całej sytuacji wybrnąć (próbował ją więc oddać Amerykanom). Nie zdołał też ustalić nic konkretnego w sprawie nielegalnego handlu bronią - czego można oczekiwać od tradycyjnego reportażu śledczego. Postać Pułkownika do końca reportażu pozostała niezdemaskowana, jego los polski reporter znał tylko pośrednio, a na dodatek nie wyciągnął z opisanej historii żadnych wniosków, sam stał się jednak centralną postacią tekstu, próbując (w trochę groteskowy sposób) pozbyć się nielegalnie zdobytej broni. Reporterskie śledztwo przerasta raczej w literacki obraz, dodając reportażom Mariusza Zawadzkiego obrazowości oraz fabularności: „[...] jesteśmy z tą rakietą w bagażniku jedną wielką alegorią amerykańskiej inwazji na Irak. Łatwo ją zdobyliśmy, lecz zupełnie zapomnieliśmy zaplanować co dalej"42.

\section{Válka v Iráku očima tří českých reportérů}

Forma książki Válka v Iráku očima tři českých reportérů odpowiada aktualnej kondycji i statusowi reportażu w czeskim środowisku dziennikarskim, nie mówiąc już o środowisku literackim. Pomimo iż mamy do czynienia z książkowym wydaniem tekstów reporterskich (co w Czechach jest dość nietypowe, jak zresztą na wstępie podkreśla sam redaktor tomu Zdeněk Šámal) ${ }^{43}$, publikacja wydaje się raczej sztucznie zestawionym zbiorem wspomnień lub quasi-dziennikowych notatek, ułożonych w porządku chronologicznym oraz uzupełnionych o wyjaśniające komentarze (słowa wstępne) głównego redaktora, wprowadzające czytelnika w szerszy kontekst historyczny i polityczny. Przedmowy te w znaczący sposób są jednak stylizowane, czasami nie ukrywają subiektywnego spojrzenia na omawiane tematy, aczkolwiek w pierwszej kolejności pełnią funkcję informacyjną i wyjaśniającą.

Dobrym przykładem takiej strategii jest choćby pierwszy tekst Michala Kubala zatytułowany przez redaktora Godziny przed burza. W przedmowie czytamy:

42 Ibidem, s. 31.

43 M. Kubal, F. Šulc, B. Šámalová, Válka o Irák očima tř́ českých reportérů, Praha 2004, s. 6. 
Było oczywiste, że wojna wkrótce się rozpocznie. Czas przełyka ostatnie godziny ultimatum wyznaczonego irackiemu samowładcy Saddamowi Husajnowi oraz jego dwom synom, Udajowi i Kusajowi, przez prezydenta Stanów Zjednoczonych George’a W. Busha. Mają zrezygnować z swoich funkcji i opuścić kraj. [...] Figury zostały ustawione, wszyscy czekali na pierwszy ruch. 300 tysięcy żołnierzy koalicji czekało na sygnał do ataku ${ }^{44}$.

Obrazowość cytowanego fragmentu jest jednak dosyć stereotypowa, metafora szachów służy do opisu atmosfery wyczekiwania, zbliżająca się wojna pokazana jest jako gra strategiczna.

Wydarzenia w Iraku przedstawiane są w książce chronologicznie, czemu służy również wspomniana forma dziennika - poszczególne rozdziały opatrzone zostały wskazówkami czasowymi, każdy z rozdziałów odpowiada jednemu dniu. W każdym z nich głos zabierają wszyscy trzej reporterzy, ich teksty uzupełniają się, aczkolwiek każdy pokazuje wydarzenia danego dnia z innej perspektywy. Dzięki takiemu zabiegowi cały tom uzyskuje charakter kolażu, mozaiki.

Wykorzystanie narracji pierwszoosobowej, często w czasie teraźniejszym, zdaje się z jednej strony wskazywać na konwencję diarystyczną. Z drugiej - teksty Michala Kubala nasuwają na myśl raczej gatunek pamiętników, autor używa bowiem czasu przeszłego. Z kolei Šulc i Šámalová częściej korzystają z czasu teraźniejszego, co może być rezultatem stylizacji mającej na celu wywołanie efektu autentycznej relacji (nie zawsze taka forma stosowana jest jednak konsekwentnie).

Ocena genologiczna tekstu tego rodzaju jest dosyć skomplikowana. Trudno ustalić, czy w tym wypadku mamy do czynienia $\mathrm{z}$ autentycznym dziennikiem (czemu zdaje się przeczyć kompozycja książki, między innymi połączenie trzech rodzajów przekazu oraz tekstów trzech autorów, trochę sztucznie dostosowanych do siebie, ale także wyraźna stylizacja sporych fragmentów książki), z tekstem stylizowanym na zapiski diarystyczne czy z prawdziwym reportażem. Sam redaktor tomu pisze we wstępie, iż książka jest „dziennikiem reporterskim”45. Jeżeli próbujemy oceniać książkę Válka o Irák očima tři českých reportérů jako reportaż, okazuje się, że trafniejszym określeniem byłby na przykład quasi-dziennik zawierający elementy reportażu. Nawet $\mathrm{w}$ takim rozumieniu, uwzględniając subiektywny i osobisty wymiar tekstu, ma on jednak bliżej do reportażu publicystycznego niż literackiego (nadrzędną funkcją jest funkcja informacyjna i sprawozdawcza, obecny jest jednak wyraźny komentarz odautorski). Właśnie forma dziennika (quasi-dziennika), a więc przefiltrowanie faktów przez subiektywne przeżywanie oraz osobowość reportera, pozwala uniknąć ścisłej, suchej dokumentarności. Patrząc na książkę czeskich dziennikarzy z nieco innego punktu widzenia, można ją czytać jako swoisty komentarz autentycznych świadków wydarzeń do przebiegu wojny w Iraku, ale także jako subiektywne uzupełnienie czy

44 Ibidem, s. 7 (wszystkie tłumaczenia cytatów z książki zostały dokonane przez autorkę niniejszego tekstu).

45 Ibidem, s. 6. 
poszerzenie zwięzłych przekazów medialnych, których autorami zresztą cała trójka Kubal, Šulc i Šámalová — również była.

Książka Válka o Irák očima tři českých reportérů w pewnym sensie zbliża się do gatunku feature, formy prostszej niż reportaż (zwłaszcza w polskim rozumieniu tego terminu), przedstawiającej wydarzenia chronologicznie, ale jednocześnie tylko sugerującej problemy. Zwięzłość informacyjna łączy się w tym gatunku z efektownym sposobem pisania i atrakcyjnością dla czytelnika, zazwyczaj kosztem ominięcia niektórych faktów czy szczegółów. Kazimierz Wolny-Zmorzyński pisze wprost, że „to forma dla mało ambitnych i chcących konkurować z szybkością przekazu informacji w mediach elektronicznych [reporterów - M.B.]"46. Co prawda, cecha ta znika po trosze w momencie, gdy czytamy książkę jako całość — jeżeli spojrzymy jednak na poszczególne teksty („zapiski dziennikowe”), wyżej wspomniane cechy feature uwypuklają się. Dla czeskich dziennikarzy ważne jest oddanie atmosfery, co widać na przykład we wspomnianej już formie (quasi)diarystycznej narracji pierwszoosobowej. Autorzy często skupiają się na pojedynczych wydarzeniach, kompozycja takiego tekstu jest mniej skomplikowana niż w tradycyjnym reportażu. Owym atrakcyjnym tematem jest w wypadku książki Válka o Irák očima tř́ českých reportérů spojrzenie na pracę dziennikarzy w skomplikowanych warunkach. Korzystanie z takiej formy nie wiąże się w Czechach tylko z czynnikami komercyjnymi czy coraz bardziej dynamicznym sposobem działania świata medialnego - reportaż, zwłaszcza reportaż literacki, nie ma bowiem w Czechach silniejszej tradycji ${ }^{47}$.

Warto również dodać, że teksty trójki czeskich dziennikarzy uzupełnione zostały nie tylko o komentarze redaktora, ale także o słowniczek zawierający i wyjaśniający podstawowe pojęcia, na przykład humvee, „chytre bomby” lub Seabees. Kolejne aneksy przytaczają informacje o „najważniejszych jednostkach lądowych walczących stron”, dziennikarzach, którzy zginęli podczas wojny w Iraku, i stopniach wojskowych w Siłach Zbrojnych Stanów Zjednoczonych oraz Republiki Czeskiej. Takiego rodzaju dodatki spełniają funkcję ściśle informacyjną. Dołączone zostały także zdjęcia tematycznie powiązane $\mathrm{z}$ opisywanymi wydarzeniami (również to może przypominać konwencję feature).

46 K. Wolny-Zmorzyński, Poetyka reportażu polskiego po 1989 roku. Zarys problematyki, [w:] Reportaż a przemiany społeczne po 1989 roku, red. K. Wolny-Zmorzyński, W. Furman, Kraków-Rzeszów 2005, s. 26.

47 Nie sposób poświęcić w tym tekście więcej uwagi odrębnej tradycji reportażu w Polsce i w Czechach. Czytelników zainteresowanych tą problematyką odsyłam na przykład do tekstu: L. Zakopalová, Český kontext: recepce, překlady a domácí tradice, [w:] M. Benešová, R. Rusin Dybalska, L. Zakopalová a kol., Fenomén: Polská literární reportáž, Praha 2016, s. 73-96. Należy również zwrócić uwagę, że Michal Kubal i Barbora Šámalová otrzymali w 2004 roku czeską Nagrodę im. Ferdinanda Peroutki dla najlepszych dziennikarzy, właśnie za relacjonowanie wojny irackiej (aczkolwiek wzięto pod uwagę przede wszystkim ich relacje telewizyjne z Iraku). 
Teksty Michala Kubala, w tym czasie korespondenta Czeskiej Telewizji, najbardziej przypominają reportaż literacki. Jednak również on skupia się $-\mathrm{w}$ formie diarystycznej - przede wszystkim na własnej pracy dziennikarskiej lub na ogólnych spostrzeżeniach dotyczących pracy dziennikarzy w trudnych warunkach wojennych. Interesuje go dziennikarska codzienność, rekonstruuje (stosując czas przeszły) własne doświadczenia: „Od samego początku chcieliśmy być w Iraku dokładnie w chwili wybuchu wojny" ${ }^{38}$. Następnie śledzimy reakcje Kubala i jego kamerzysty Petra Klímy w momencie, kiedy konflikt naprawdę wybucha. Reportaże Kubala zawierają między innymi mnóstwo praktycznych informacji, na przykład:

Pobyt w Iraku nie był tani. Za każdego dziennikarza lub członka ekipy sto dolarów dziennie, sto za kamerę, kolejna stówa za notebooka i kto zabiera z sobą telefon satelitarny, musi zapłacić 150 dolarów dziennie. Dla normalnie wyposażonej dwuosobowej ekipy mniejszej telewizji, takiej jak nasza Czeska Telewizja, oznaczało to codzienne wydatki w wysokości 550 dolarów, na co nie mogliśmy sobie pozwolićs ${ }^{4}$.

Na szczęście Kubalowi udało się wynegocjować zniesienie opłat. W odróżnieniu od Smoleńskiego i Zawadzkiego, którzy pojawili się w Iraku później, ekipa Czeskiej Telewizji zmuszona była do korzystania z usług oficjalnego tłumacza i przewodnika zabraniającego kręcenia reportaży w niektórych miejscach itp.

Kubal ciekawie opisuje również regularną armię iracką i jej rozkład po rozpoczęciu inwazji. Barwny opis żołnierzy Saddama Husajna zestawia z informacyjnymi fragmentami (kiedy zaczęło się bombardowanie, jakie były powody ataku, kto poniósł jakie straty itp.). Kontrast jest wyraźny — opis armii irackiej jest bowiem ekspresywny, silnie nacechowany, miejscami nawet ironiczny. W ten sposób reporter zwraca uwagę na codzienną iracką rzeczywistość, różną od oficjalnych (mainstreamowych) przekazów medialnych, ale także oficjalnej propagandy irackiej.

Wszędzie widać było grupy milicjantów, brzuchatych tatusiów i młodych chłopców z kałasznikowami. Reprezentowali jedyną siłę zbrojną na ulicach [...]. Wojownicy iraccy najbardziej przypominali armię mrówek z serii o pszczółce Mai, uczącą się marszu „siano-słoma” ${ }^{50}$.

Zarówno owe fragmenty informacyjne, jak i wypowiedzi stylizowane uzupełnione zostały komentarzami bądź samego autora, bądź jego kolegi Petra Klímy. Komentarze te zazwyczaj przekazywane są językiem potocznym, ujęte są w cudzysłów, bez stylizacji (na przykład: „To przecież niemożliwe, wysłać coś takiego przeciwko tym profesjonalnym bydlakom z jednostek specjalnych") ${ }^{51}$. Reporter nie boi się wzbogacania tekstu o własne subiektywne spostrzeżenia wyraźnie ujawniające jego osobisty punkt widzenia. Również takie fragmenty umacniają diarystyczną stylizację książki.

\footnotetext{
48 M. Kubal, F. Šulc, B. Šámalová, op. cit., s. 9.

49 Ibidem, s. 10.

50 Ibidem, s. 24.

51 Ibidem.
} 
Z całej trójki czeskich dziennikarzy to właśnie Kubal najczęściej sięga po środki artystyczne, znane $z$ tradycji polskiego reportażu literackiego. Przykładowo obraz drugiego dnia walk w Bagdadzie otwiera przytoczeniem sceny ze starego jugosłowiańskiego filmu sławiącego bohaterską walkę komunistycznych partyzantów jugosłowiańskich z nazistami podczas drugiej wojny światowej, który telewizja iracka właśnie w tym czasie transmitowała. Zwraca uwagę na interesującą paralelę odwołującą się zarówno do głównych zasad działania ówczesnej irackiej propagandy, jak i do niektórych absurdalnych cech medialnego obrazu wojny w Iraku. Jednocześnie taki obraz staje się oryginalnym wprowadzeniem do reportażu o drugim dniu bitwy o Bagdad, przybliżając czeskiemu czytelnikowi perspektywę przeciętnego mieszkańca stolicy Iraku. Kubal zastanawia się, jak zwykli Irakijczycy przeżywali wojnę i jak różniła się ona od ich wyobrażeń.

Inne ciekawe wątki reportaży Michala Kubala (oprócz opisu operacji militarnych w Bagdadzie) przytoczę już tylko w skrócie: czeski reporter pisze na przykład o żywych tarczach (historia Amerykanina, który przyjechał do Iraku, żeby stać się żywą tarczą i w ten sposób protestować przeciwko polityce prezydenta Busha) ${ }^{52}$, porównuje tak zwaną drugą wojnę w Zatoce Perskiej do tej pierwszej z początku lat dziewięćdziesiątych, często pisze o irackiej propagandzie.

František Šulc, podobnie jak Mariusz Zawadzki, stara się zrekonstruować sposób myślenia żołnierzy amerykańskich i ich dowódców: „Dla wszystkich było jasne, że prezydent Bush podjął właściwą decyzję, USA uwolnią Irakijczyków i ochronią świat przed człowiekiem, który chce go zdominować"53. Także Šulc uprawiał embedded journalism, został przydzielony do jednostek Seabees. Razem z nimi odwiedza na przykład płonące szyby naftowe, przeżywa burzę piaskową czy obserwuje budowanie nowych mostów. Szczegółowo pisze o zasadach pracy z amerykańskimi żołnierzami, zdradza, o czym dziennikarz w takiej sytuacji może pisać, a jakie tematy stają się tabu. Śledzi sytuacje, w których szeregowi żołnierze stają się bohaterami, ale także codzienne życie wojaków. Częściej niż Kubal pisze o ludziach, których spotkał podczas swojej pracy w Kuwejcie (nie zawsze chodzi wyłącznie o żołnierzy). Ich losy stały się materiałem do reportaży prasowych Šulca, w książce Válka o Irák očima tři českých reportérů mamy więc do czynienia tylko z echami tych rozmów oraz z drobnymi refleksjami reportera.

Barbora Šámalová, również korespondentka Czeskiej Telewizji, relacjonowała wojnę w Iraku razem z kamerzystą Markiem Ondříčkiem. Dziennikarka skupia się przede wszystkim na działalności czesko-słowackiej jednostki antychemicznej stacjonującej w Kuwejcie. Nie była jedyną reporterką zaintrygowaną tym tematem - okazało się, że zainteresowanie zagranicznych dziennikarzy jednostką czesko-słowacką jest ogromne. „W szarej nudzie setek powtarzających się historii chemicy są jednym

52 Ibidem, s. 161-164.

53 Ibidem, s. 12. 
z największych ożywień, na które można w Kuwejcie i tutejszych bazach wojskowych natrafić" 54 . Szczegółowo opisuje również sytuację czeskich dziennikarzy, czasami nawet w zabawny, nieco autoironiczny sposób: „Czeska Telewizja nikogo nie interesuje. Zawsze tak jest, nie spotykam się z czymś takim po raz pierwszy ani nie jestem zaskoczona. Czesi to po prostu mały naród. Jestem zadowolona, że tym razem nie pomylili nas z Czeczenami”"55. Kiedy wybiera się z konwojem humanitarnym do Iraku, od razu zauważa zmianę nastroju: „Zmiana jest zdumiewająca. Od razu znajdujemy się w innym świecie. Wokół autobusów roi się od dziesiątek brudnych dzieciaków patrzących na nas nieśmiało. Machają rękami i pokazują, że chcą trochę wody albo coś do jedzenia" ${ }^{\text {"W }}$. Właśnie w takich momentach, wysłuchując rozmaitych opowieści Irakijczyków podczas rozdzielania pomocy humanitarnej i starając się zrozumieć, dlaczego obywatele Iraku wbrew pozorom nie są zachwyceni obecnością wojsk koalicyjnych, Šámalová ma najbliżej do reportażu w postaci, jaką zna polska tradycja.

\section{The war in Iraq through the eyes of Polish and Czech reporters: The example of texts by Paweł Smoleński, Mariusz Zawadzki, Michal Kubal, František Šulc and Barbora Šámalová}

Summary

This paper analyzes three reportage books focusing on the war in Iraq in 2003. Two reportages are Polish, the authors of the third book are Czech journalists. Paweł Smoleński focuses primarily on the knowledge of Iraqi culture and mentality in the face of building a new Iraq after the fall of Saddam Hussein. The armed conflict itself remains somewhat in the background of the reporter's interest. Smoleński's texts are closest to so-called literary coverage. Mariusz Zawadzki as an embedded correspondent - among other things - accompanied U.S. troops to cover combat operations. The texts of Czech reporters, some of which were in Iraq since the very beginning, are closer to the so-called "feature". In addition, they are stylized as a reporter quasi-diary.

54 Ibidem, s. 19.

55 Ibidem, s. 68.

56 Ibidem, s. 137. 